\title{
PENGARUH GOOD CORPORATE GOVERNANCE TERHADAP KINERJA KARYAWAN PERUSAHAAN BUMN (Studi Pada Karyawan BRI Unit Ratu Samban Kota Bengkulu)
}

\author{
Ahmad Junaidi ${ }^{1}$, Nensi Yuniarti. $\mathbf{Z s}^{2}$, Lia Radiana ${ }^{3}$ \\ ${ }^{1,2,3}$ FakultasEkonomi dan Bisnis Universitas Muhammadiyah Bengkulu \\ Email : ahmadjunaidi@umb.ac.id, nensiyuniarti@umb.ac.id, Liaradiana22@gmail.com
}

\begin{abstract}
ABSTRAK
Penelitian ini bertujuan untuk menguji seberapa besar pengaruh Good Corporate Governance, yang diwakili oleh keterbukaan (transparency), akuntabilitas (accountability), tanggung jawab (reaponsibility), kemandirian (independency), dan kewajaran (fairness) terhadap kinerja karyawan pada bank BRI Unit Ratu Samban Kota Bengkulu. Jenis metode penelitian yang digunakan dalam penelitian ini adalah metode kuantitatif, dengan menggunakan teknik pengumpulan data melalui penyebaran kuesioner (angket). Responden yang berpartisipasi pada penelitian ini sebanyak 30 orang karyawan yang berasal dari seluruh karyawan pada bank BRI Unit Ratu Samban Kota Bengkulu. Dengan menggunakan teknik analisis data regresi linear berganda, hasil penelitian ini dapat disimpulkan bahwa konstanta sebesar 11,127 menyatakan bahwa nilai konstanta positif menunjukan pengaruh positif antara variabel independen dengan variabel dependen, yaitu transparancy, accountability, responsibility, independency, dan fairness mengalami peningkatan, serta kinerja karyawan akan mengalami peningkatan juga.
\end{abstract}

Kata Kunci : Transparancy, Accountability, Responsibility, Independency,dan Fairness, dan Kinerja Karyawan

\section{ABSTRACT}

This study aims to examine how much influence Good Corporate Governance, which is represented by transparency, accountability, reaponsibility, independence and fairness on the performance of employees in BRI Ratu Unit Unit Ratu Samban Bengkulu City. The type of research method used in this study is a quantitative method, using data collection techniques through questionnaires. Respondents who participated in this study were 30 employees from all employees of the BRI Samban Unit, Bengkulu City Bank Bengkulu. By using multiple linear regression data analysis techniques, the results of this study can be concluded that a constant of 11.127 states that a positive constant value shows a positive influence between the independent variable and the dependent variable, namely transparency, accountability, responsibility, independence, and fairness has increased, and employee performance will experience an increase too.

Keywords: Transparency, Accountability, Responsibility, Independence, and Fairness, and Employee Performance. 


\section{PENDAHULUAN}

Di era ekonomi global yang semakin maju saat ini, akan menimbulkan persaingan usaha yang semakin ketat. Indonesia merupakan negara yang memiliki potensi ekonomi yang tinggi, potensi tersebut mulai diperhatikan secara global, banyak perusahaan baru berdatangan menjadi saingan perusahaan yang telah lama dibentuk. Untuk tetap mempertahankan performa perusahaan dari saingan-saingan yang ada yang harus dilakukan adalah meningkatan kinerja, baik dari segi kinerja perusahaan maupun kinerja karyawan. Perusahaan harus mampu mengelola sumber daya yang dimiliki dengan seoptimal mungkin untuk mencapai kinerja yang prima. Kinerja perusahaan tentunya tidak dapat dipisahkan dengan kinerja karyawan yang merupakan penggerak utama suatu perusahaan. Semakin pesatnya kemajuan teknologi dan semakin banyaknya kompetitor usaha yang berada baik di dalam maupun di luar negeri, maka perusahaan diharapkan dapat meningkatkan kinerja internal dan eksternal untuk dapat bersaing dalam kancah bisnis dalam negeri maupun luar negeri.

Perusahaan sebagai sebuah organisasi memiliki dua permasalahan dalam menjalankan fungsi dan tujuannya, yakni permasalahan internal dan eksternal. Permasalahan internal adalah permasalahan-permasalahan yang terjadi di dalam perusahaan itu sendiri, yang merupakan permasalahan yang umum dan sudah sewajarnya terjadi karena dalam suatu perusahaan terdiri atas berbagai manusia dengan berbagai macam karakteristik, sifat, dan pemikiran sehingga hal-hal ini kemudian menimbulkan gesekan dan pertentangan-pertentangan yang pada akhirnya menimbulkan konflik. Permasalahan eksternal adalah permasalahan yang terjadi, yang dipengaruhi oleh faktor dari luar perusahaan, misalnya kebijaksanaan pemerintah di bidang politik, ekonomi, hukum, teknologi dan tingkat persaingan yang semakin ketat (Jimmy Joses Sembiring, 2010:1). Persaingan menjadi suatu kondisi yang perlu diperhatikan oleh setiap perusahaan, maka perusahaan harus memiliki strategi yang dapat dijadikan sebagai senjata dalam memenangkan persaingan yang ada. Perusahaan yang mampu bersaing dan memiliki kinerja yang baik dapat diwujudkan dengan mengimplementasikan penerapan Good Corporate Governance (GCG) dapat dilihat dari salah satu tujuan penting di dalam mendirikan sebuah perusahaan yang selain untuk meningkatkan kesejahteraan semua elemen dari perusahaan termasuk juga di dalamnya karyawan.

Pada dasarnya implementasi Good Corporate Governance (GCG) pada lembaga perbankan menjadi sebuah keharusan karena aset fisik dari perbankan adalah nasabahnya, sehinggap perbankan harus menjaga kepercayaan nasabah bahwa dana yang tersimpan akan dikelola dengan baik dan aman. Pelaksanaan Good Corporate Governance (GCG) pada industri perbankan harus berlandaskan pada lima prinsip dasar, keterbukaan (transparancy), akuntabilitas (accountability), pertanggung jawaban (responsibility), independensi (independency) dan kewajaran (fairness). Manajemen sumber daya manusia merupakan suatu perencanaan, pengorganisasian, pengkoordinasian, pelaksanaan dan pengawasan terhadap pengadaan, pengembangan, pemberian balas jasa, pengintegrasian, pemeliharaan dan pemisahan tenaga kerja dalam rangka mencapai tujuan organisasi (Anwar Prabu Mangkunegara, 2011:2).

Perusahaan Badan Usaha Milik Negara (BUMN) adalah sasaran utama pemerintah Indonesia untuk dapat menerapkan prinsip-prinsip tata kelola perusahaan yang baik atau Good Corporate Governance (GCG), karena BUMN adalah pelaku utama didalam ekonomi Indonesia. Hampir setiap warga Negara membutuhkan produksi dari BUMN, dengan keanekaragaman sektor usaha yang dimilikinya. Salah satunya yang merupakan bagian dari perusahaan BUMN adalah Bank Rakyat Indonesia (BRI) yang bergerak dibidang perbankan. Bank Rakyat Indonesia (BRI) memiliki 
fungsi yang sama pada bank-bank lainnya yaitu menghimpun dana dari masyarakat dalam bentuk simpanan dan menyalurkannya kepada masyarakat dalam bentuk kredit dan atau dalam bentukbentuk lainnya dalam rangka meningkatkan taraf hidup masyarakat. Karena itulah Penelitian ini akan dilakukan pada perusahaan BRI yang berada di Unit Ratu Samban Kota Bengkulu.

\section{TINJAUAN LITERATUR}

\section{Definisi Good Corporate Governance.}

Good Corporate Governance (GCG) atau tata kelola perusahaan yang baik adalah suatu tata kelola yang menerapkan prinsip-prinsip keterbukaan (transparancy), akuntabilitas (accountability), pertanggung jawaban (responsibility), independensi (independency), dan kewajaran (fairness). Tata kelola yang baik menuntut dibangun dan dijalankannya prinsip tersebut dalam proses manajerial (Hamdani, 2016:22). Good Corporate Governance (GCG) pada dasarnya merupakan suatu sistem (input, process, output) dan seperangkat peraturan yang mengatur hubungan antara berbagai pihak yang berkepentingan (stakeholders) demi tercapainya tujuan perusahaan. GCG dimasukkan untuk mengatur hubungan-hubungan tersebut dan mencegah terjadinya kesalahan yang signifikan dalam strategi perusahaan dan untuk memastikan bahwa kesalahan-kesalahan yang terjadi dapat diperbaiki dengan segera (Moh. Wahyudi Zarkasyi, 2014:12).

Dalam buku Daniri, (2014:10) prinsip-prinsip tersebut dapat dijabarkan sebagai berikut :

\section{Keterbukaan(Transparancy).}

Transparansi bisa diartikan sebagai keterbukaan informasi, baik dalam proses pengambilan keputusan maupun dalam mengungkapkan informasi material dan relevan mengenai kegiatan perusahaan.

2. Akuntabilitas(Accountability).

Akuntabilitas adalah kejelasan fungsi, struktur, sistem dan pertanggung jawaban organ perusahaan sehingga pengelolaan perusahaan terlaksanakan secara efektif.

3. Pertanggung Jawaban(Responsibility).

Pertanggung jawaban perusahaan adalah kesesuaian (kepatuhan) di dalam pengelolaan perusahaan terhadap prinsip korporasi yang sehat serta peraturan perundangan yang berlaku. Peraturan yang berlaku disini termasuk yang berkaitan dengan masalah pajak, hubungan industrial, perlindungan lingkungan hidup, kesehatan/keselamatan kerja, standar penggajian dan persaingan yang sehat.

\section{Kemandirian (Independency).}

Kemandirian merupakan prinsip penting dalam penerapan GCG di Indonesia. Independensi atau kemandirian adalah suatu keadaan dimana perusahaan dikelola secara profesional tanpa benturan kepentingan dan pengaruh/tekanan dari pihak manapun yang tidak sesuai dengan peraturan perundang-undangan yang berlaku dan prinsip-prinsip korporasi yang sehat.

\section{Fairness (Kewajaran).}

Secara sederhana kesetaraan dan kewajaran bisa didefinisikan sebagai perlakuan yang adil dan setara didalam memenuhi hak-hak stakeholders yang timbul berdasarkan perjanjian serta peraturan perundangan yang berlaku.

\section{Penilaian Kinerja Karyawan.}

Sumber daya manusia merupakan salah satu unsur penting dalam perusahaan perbankan maupun perusahaan lainnya, untuk mencapai tujuan dari perusahaan tersebut didirikan yang 
mencakup perekrutan tenaga kerja, mengembangkan potensi, dan keterampilan tenaga kerja yang bertujuan untuk meningkatkan efektivitas dan efisiensi kerja agar memberikan keuntungan semaksimal mungkin bagi perusahaan yang bersangkutan (Jimmy Joses Sembiring, (2010:14). Kinerja merupakan suatu kondisi yang harus diketahui dan dikonfirmasikan kepada pihak tertentu untuk mengetahui tingkat pencapaian hasil yang dihubungkan dengan visi yang diemban oleh individu atau suatu organisasi dari suatu kebijakan operasional. Kinerja adalah perubahan produktivitas yang didapat seseorang yang melakukan pekerjaan atau aktivitas sesuai pekerjaannya. Kinerja yang baik adalah apabila seseorang melakukan pekerjaan sesuai dengan profesinya dan mendapatkan hasil sesuai dengan harapan.

\section{Hipotsis.}

$\mathbf{H}_{1}$ Variabel Transparancy $\left(\mathrm{X}_{1}\right)$, Accountability $\left(\mathrm{X}_{2}\right)$, Responsibility $\left(\mathrm{X}_{3}\right)$, Independency $\left(\mathrm{X}_{4}\right)$ danFairness $\left(\mathrm{X}_{5}\right)$ secara simultan memiliki pengaruh yang signifikan terhadap Kinerja Karyawan (Y).

$\mathbf{H}_{2}$ Variabel Transparancy $\left(\mathrm{X}_{1}\right)$ secara parsial memiliki pengaruh yang signifikanterhadap Kinerja Karyawan (Y).

$\mathbf{H}_{3}$ VariabelAccountability $\left(\mathrm{X}_{2}\right)$ secara parsial memiliki pengaruh yang signifikan terhadap Kinerja Karyawan(Y).

$\mathbf{H}_{4}$ Variabel Responsibility $\left(\mathrm{X}_{3}\right)$ secara parsial memiliki pengaruh yang signifikan terhadap Kinerja Karyawan (Y).

H5 Variabel Independency $\left(\mathrm{X}_{4}\right)$ secara parsial memiliki pengaruh yang signifikan terhadap Kinerja Karyawan (Y).

H6 Variabel Fairness $\left(\mathrm{X}_{5}\right)$ secara parsial memiliki pengaruh yang signifikan terhadap Kinerja Karyawan (Y).

\section{METODE PENELITIAN}

Penelitian ini bertujuan untuk menguji apakahadapengaruh Good Corporate Governance terhadap kinerja karyawan pada bank BRI Unit Ratu Samban Kota Bengkulu. Jenis penelitian yang digunakandalampenelitianiniadalahmetodesurveyyaitupengumpulan data primer denganpendekatan kuantitatif, menggunakanteknik pengumpulan datamelalui penyebarankuesioner (angket) yang bertujuanuntuk menentukan kesamaan status dengan cara membandingkan dengan standar yang sudah dipilih atau ditentukan, dan disamping itu juga untuk membuktikan atau membenarkan suatu hipotesis. Variabel yang akanditelitiadalahvariabel bebas (independen) yaitutransparancy $\left(\mathrm{X}_{1}\right)$, accountability $\left(\mathrm{X}_{2}\right), \quad$ responsibility $\left(\mathrm{X}_{3}\right)$, independency $\left(\mathrm{X}_{4}\right), \quad$ dan fairness $\left(\mathrm{X}_{5}\right)$ terhadapvariabelterkait (dependen) kinerjakaryawan $(\mathrm{Y})$.

Populasi dan sampel dalam penelitian ini yaitu seluruh karyawan pada bank BRI Unit Ratu Samban Kota Bengkulu. Responden yang berpartisipasi pada penelitian ini sebanyak 30 orang karyawan. Dengan jumlah data yang diolahuntukpenelitian ini sebanyak 30kuesioner yang berasal dari seluruh karyawan pada bank BRI Unit Ratu Samban Kota Bengkulu. Dalam penelitian ini teknik analisis data yang peneliti gunakan untuk menguji data adalah dengan Uji Validitas, Uji Reliabilitas, Uji Normalitas, AnalisisRegresi Linear Berganda, dan Analisis Verifikatif yaitu : 
rancangan pengujian hipotesis data terhadap pengaruh koefisien determinasi $\left(\mathrm{R}^{2}\right)$, pengaruh variabel secara simultan (uji F) dan pengaruh perisal (uji t) dengan bantuan program SPSS (Stastistical Package for the Social Science).

\section{HASIL DAN PEMBAHASAN.}

\section{Hasil Uji Validitas}

a) Keterbukaan (transparancy) mempunyai kriteria valid karena dapat dilihat bahwa skor masingmasing butir dan total menunjukkan korelasi signifikat kurang dari 0,05 sehingga dinyatakan valid. Jadi dapat disimpulkan bahwa masing-masing pertanyaan adalah valid.

b) Akuntabilitas (Accountability) mempunyai kriteria valid karena dapat dilihat bahwa skor masing-masing butir dan total menunjukkan korelasi signifikat kurang dari 0,05 sehingga dinyatakan valid.

c) Tanggung jawab (Responsibility) mempunyai kriteria valid karena dapat dilihat bahwa skor masing-masing butir dan total menunjukkan korelasi signifikat kurang dari 0,05 sehingga dinyatakan valid.

d) Kemandirian (Independency) mempunyai kriteria valid karena dapat dilihat bahwa skor masingmasing butir dan total menunjukkan korelasi signifikat kurang dari 0,05 sehingga dinyatakan valid.

e) Kewajaran (Fairness) mempunyai kriteria valid karena dapat dilihat bahwa skor masing-masing butir dan total menunjukkan korelasi signifikat kurang dari 0,05 sehingga dinyatakan valid.

\section{Hasil Uji Reliabilitas.}

Berdasarkan pengujian yang telah dilakukan berikut ditampilkan hasil uji Reliabilitas dalam penelitian ini:

\section{Hasil Pengujian Reliabilitas}

\begin{tabular}{|l|c|c|c|}
\hline \multicolumn{1}{|c|}{ Variabel } & $\begin{array}{c}\text { Jumlah } \\
\text { instrumen }\end{array}$ & $\begin{array}{c}\text { Cronbach's } \\
\text { Alpha }\end{array}$ & Keterangan \\
\hline Keterbukaan (transparancy) & 3 & 0,654 & Reliabel \\
\hline Akuntabilitas (Accountability) & 3 & 0,631 & Reliabel \\
\hline Tanggung jawab (Responsibility) & 3 & 0,696 & Reliabel \\
\hline Kemandirian (Independency) & 3 & 0,703 & Reliabel \\
\hline Kewajaran (Fairness) & 3 & 0.610 & Reliabel \\
\hline Kinerja Karyawan & 15 & 0.900 & Reliabel \\
\hline
\end{tabular}

Berdasarkan Table di atas menunjukkan bahwa hasil pengujian Reliabilitas memperoleh Croanbach's Alpha lebih dari0,60 yang artinya semua variabelmenunjukkan Reliable.

\section{Hasil Uji Normalitas}

Berdasarkan pengujian yang telah dilakukan berikut ditampilkan hasil uji Normalitas dalam penelitian ini: 


\section{Hasil Pengujian Normalitas}

One-Sample Kolmogorov-Smirnov Test

\begin{tabular}{|ll|r|}
\hline & & $\begin{array}{c}\text { Unstandardized } \\
\text { Residual }\end{array}$ \\
\hline$N$ & Mean & 30 \\
Normal Parameters ${ }^{a, b}$ & Std. Deviation &, 0000000 \\
& Absolute & 1,46509909 \\
Most Extreme & Positive &, 104 \\
Differences & Negative &, 104 \\
& &,- 079 \\
Kolmogorov-Smirnov Z & &, 571 \\
Asymp. Sig. (2-tailed) & &, 901 \\
\hline
\end{tabular}

Berdasarkan hasil pengujian one sampel kolmogrov smirnov (KS), terlihat bahwa semua variabel memiliki asymp. Sig (2-tailed) lebih besar dari $\alpha=0,05$ yaitu sebesar ,901. Ini menunjukan semua variabel telah terdistribusi secara normal dengan nilai probabilitas $>0,05$ yang artinya data telah terdistribusi secara normal.

\section{Analisis Regresi Linier Berganda}

Berdasarkan pengujian yang telah dilakukan berikut ditampilkan hasil Analisis Regresi Linier Berganda dalam penelitian ini:

\section{Hasil Uji Linear Berganda}

Coefficients ${ }^{a}$

\begin{tabular}{|c|c|c|c|c|c|}
\hline \multirow[t]{2}{*}{ Model } & \multicolumn{2}{|c|}{$\begin{array}{c}\text { Unstandardized } \\
\text { Coefficients }\end{array}$} & $\begin{array}{c}\text { Standardized } \\
\text { Coefficients }\end{array}$ & \multirow[t]{2}{*}{$t$} & \multirow[t]{2}{*}{ Sig. } \\
\hline & $B$ & Std. Error & Beta & & \\
\hline (Constant) & 11,127 & 5,054 & & 2,202 & ,038 \\
\hline $\mathrm{X} 1$ & ,760 & ,349 & ,216 & 2,176 &, 040 \\
\hline $\mathrm{X} 2$ & ,754 & ,284 & ,222 & 2,657 &, 014 \\
\hline $\mathrm{X} 3$ & ,710 & ,332 & 221 & 2,138 & 043 \\
\hline $\mathrm{X} 4$ & 1,143 & ,186 & ,510 & 6,137 & ,000 \\
\hline X5 & 1,032 & 289, & ,313 & 3,576 & ,002 \\
\hline
\end{tabular}

Model $: \mathrm{Y}=\alpha+\beta_{1} \mathrm{X} 1+\beta_{2} \mathrm{X} 2+\beta_{3} \mathrm{X} 3+\beta_{4} \mathrm{X} 4+\beta_{5} \mathrm{X} 5+\varepsilon$

$$
=11,127+0,760+0,754+0,710+1,143+1,032+\varepsilon
$$




\section{Pengaruh Transparancy Terhadap Terhadap Kinerja Karyawan.}

Berdasarkan pengujian yang telah dilakukan maka dapat disimpulkan bahwa prinsip transparancy memiliki pengaruh signifikan yang positif terhadap kinerja karyawan, yang mana artinya bahwa apabila prinsip transparancy dilakukan dengan baik maka akan semakin tinggi pula kinerja karyawan, atau sebaliknya jika prinsip transparancy tidak dapat dilakukan dengan baik maka kinerja karyawan juga semakin buruk. Menurut Daniri (2014:10) transparansi diartikan sebagai keterbukaan informasi, baik dalam proses pengambilan keputusan maupun dalam mengungkapkan informasi material dan relevan mengenai perusahaan. Dalam mewujudkan transparansi, perusahaan harus menyediakan informasi yang cukup, akurat, dan tepat waktu kepada berbagai pihak yang berkepentingan dengan perusahaan tersebut.

Penelitian ini sejalan dengan penelitian yang dilakukan oleh Jayanti (2016) Hasil pengujian hipotesis koefisien regresi variabel transparancy dapat dituliskan variabel memiliki nilai koefisien regresi yang sebesar 0,468. Didapatkan nilai t hitung sebesar 2,031 dan didapatkan nilai signifikan sebesar 0,047. Nilai statistik uji t hitung tersebut lebih besar dari pada t tabel $(2,031>1,671)$ dan nilai signifikansi lebih kecil dari pada $\alpha=0,05$. Pengujian ini menunjukkan bahwa $\mathrm{H}_{0}$ tidak didukung dan $\mathrm{H}_{2}$ didukung.

\section{Pengaruh Accountability Terhadap Terhadap Kinerja Karyawan.}

Berdasarkan hasil penelitian ini dapat disimpulkan bahwa prinsip accountability memiliki pengaruh signifikan yang positif terhadap kinerja karyawan, yang mana artinya bahwa apabila prinsip fairness dilakukan dengan baik maka akan semakin tinggi pula kinerja karyawan, atau sebaliknya jika prinsip accountability tidak dapat dilakukan dengan baik maka kinerja karyawan juga semakin buruk. Penelitian ini sejalan dengan penelitian yang dilakukan oleh Didin (2018), yang menyatakan bahwa variabel $X_{1}$ dan $X_{2}$ memiliki nilai $P$ value kurang dari 0.05, sehingga keputusan tolak Ho, jadi dapat disimpulkan bahwa yang mempengaruhi Kinerja secara signifikan atau nyata pada PT Pupuk Kujang adalah transparansi, akuntabilitas. Serta didukung penelitian yang dilakukan oleh Darmawansyah (2013) bahwa dengan adanya prinsip accountability pada perusahaan memungkinkan pengawasan yang efektif terhadap setiap aktivitas perusahaan dan lebih terkontrol sehingga kinerja karyawan lebih terkoordinir dan lebih efisien. Apabila kinerja karyawan dimudahkan dengan adanya koordinasi yang tercipta dari prinsip accountability maka diidapat kinerja karyawan meningkat pula.

\section{Pengaruh Responsibility terhadap terhadap Kinerja Karyawan.}

Hasil penelitian menunjukkan bahwa tanggung jawab mempunyai pengaruh yang positif dan signifikan terhadap kinerja karyawan, hal ini berarti bahwa perusahaan akan menjadi professional dan penuh etika, menghindari penyalahgunaan kekuasaan, sehingga akan meningkatkan kinerja karyawan juga perusahaan. Kesesuaian di dalam pengelolaan perusahaan terhadap peraturan perundang-undangan yang berlaku dan prinsip-prinsip korporasi yang sehat. Perusahaan menyadari akan adanya tanggung jawab sosial, menghindari penyalahgunaan wewenang kekuasaan, menjadi professional dan menjunjung etika dan memelihara bisnis yang kuat, Suci dan Khairani (2010). Penelitian ini sejalan dengan penelitian yang dilakukan oleh Marniati (2010) yang menjelaskan melalui nilai yang didapat antara prinsip responsibility dengan kinerja karyawan Dan diperkuat oleh tujuan penerapan dari prinsip good corporate governance yang salah satu prinsipnya adalah 
responsibility atau responsibility berlandaskan Keputusan Menteri Nomor 117/MMBU/2002 pasal 4 yaitu dalam menjalankan tindakan dilandasi nilai moral yang tinggi dan kepatuhan terhadap peraturan perundangan-undangan yang berlaku serta kesadaran akan adanya tanggung jawab sosial BUMN terhadap stakeholders. penelitian yang sama juga dilakukan oleh Febriani (2016) yang mengungkapkan Pada variabel responsibility di PT Pos Indonesia (Persero) Tuban seperti perusahaan memelihara lingkungan bisnis yang sehat dan perusahaan memiliki kode etik yang diterapkan pada seluruh karyawanya telah dilaksanakan dengan baik dan tepat.

\section{Pengaruh Independency terhadap terhadap Kinerja Karyawan.}

Hasil penelitian ini menunjukkan bahwa prinsip Independency memiliki pengaruh signifikan yang positif terhadap kinerja karyawan. hal ini menunjukkan bahwa dalam menjalankan pekerjaan, karyawan lebih meyakini dan lebih percaya pada dirinya sendiri sehingga kinerjanya lebih terpercaya. Kemandirian suatu keadaan dimana perusahaan dikelola secara professional tanpa benturan kepentingan dan pengaruh / tekanan dari pihak manapun yang tidak sesuai dengan peraturan perundang-undangan yang berlaku dan prinsip-prinsip korporasi yang sehat, Suci dan Khairani (2010). Hubungannya dengan peningkatan kinerja karyawan, yaitu prinsip ini mengatur tentang bagaimana karyawan mampu menghindari terjadinya dominasi yang tidak wajar oleh stakeholders, Alpi (2019). Penelitian ini sejalan dengan penelitian Suci dan Khairani (2010) dan Alpi (2019), hasil penelitian menunjukkan bahwa kemandirian mempunyai pengaruh yang positif dan signifikan terhadap kinerja karyawan. Dengan demikian, dapat dikatakan bahwa karyawan dalam menjalankan fungsi, tugas dan tanggung jawab dalam mengelola kegiatan perusahaan bebas dari tekanan atau pengaruh, baik dari dalam maupun dari luar perusahaan. Suatu keadaan dimana perusahaan dikelola secara profesional tanpa benturan kepentingan dan pengaruh/tekanan dari pihak manapun yang tidak sesuai dengan peraturan perundang-undangan yang berlaku dan prinsip-prinsip korporasi yang sehat.

\section{Pengaruh Fairness terhadap terhadap Kinerja Karyawan.}

Hasil penelitian ini menunjukkan bahwa prinsip fairness memiliki pengaruh signifikan yang positif terhadap kinerja karyawan. Penelitian ini mengindikasikan bahwa kewajaran yang meliputi kejelasan hak-hak pemegang saham untuk melindungi kepentingan pemegang saham, termasuk perlindungan terhadap pemegang saham minoritas dari kecurangan, sehingga kinerja pegawai akan stabil karena para pemegang saham mengetahui secara detail seluruh informasi perusahaan. Prinsip kewajaran mengatur bagaimana menetapkan peran dan tanggung jawab manajemen dalam mengelola masing-masing pertanggung jawabannya. Kewajaran adalah keadilan dan kesetaraan di dalam memenuhi hak-hak stakeholders yang timbul berdasarkan perjanjian dan peraturan perundang-undangan yang berlaku, Suci dan Khairani (2010). Hasil penelitian ini sejalan dengan penelitian (Akbariyeh, 2015) dan Febriani (2016) yang menunjukkan bahwa kewajaran mempunyai hubungan yang positif dan signifika terhadap kinerja karyawan, yang dimana artinya bahwa apabila prinsip fairness dilakukan dengan baik maka akan semakin tinggi pula kinerja karyawan, atau sebaliknya jika prinsip fairness tidak dapat dilakukan dengan baik maka kinerja karyawan juga semakin buruk. 
Pengaruh transparancy, accountability, responsibility, independency dan fairness terhadap kinerja karyawan.

Dari hasil penelitian ini disimpulkan bahwa secara simultan (bersama sama) bahwa Good Corporate Governance (GCG) yang terdiri dari variabel transparancy, accountability, responsibility, independency dan fairness berpengaruh secara signifikan positif terhadap kinerja karyawan. Artinya semakin baik dalam menerapkan GCG, maka akan semakin meningkat pula kinerja karyawan. Kinerja karyawan atau kinerja Sumber Daya Manusia (SDM) adalah tingkat pencapaian prestasi atau hasil seseorang dari sasaran yang harus dicapai atau tugas yang harus dilaksanakan dalam kurun waktu tertentu, Febriani (2019). Kinerja merupakan derajat penyusunan tugas yang mengatur pekerjaan seseorang. Jadi, kinerja adalah kesediaan seseorang atau kelompok orang untuk melakukan kegiatan atau menyempurnakannya sesuai dengan tanggungjawabnya dengan hasil seperti yang diharapkan (Harsuko, n.d.). Hasil kerja tersebut dapat meningkat dengan didukung oleh penerapan dari GCG yang terdiri dari transparancy, accountability, responsibility, independency dan fairness yang telah ditetapkan. Hasil penelitian ini sejalan dengan penelitian Didin (2018) Pengaruh simultan (X1 - X5) terhadap kinerja Karyawan (Y) dengan kriteria nilai didapatkan P - value $0.000<0.05$, sehingga keputusan tolak Ho. Artinya , secara bersama - sama factor - faktor transparancy, accountability, responsibility, independency dan fairness berpengaruh signifikan terhadap kinerja karyawan PT Pupuk Kujang.

\section{KESIMPULAN DAN SARAN}

\section{Kesimpulan}

Kesimpulan yang dapat diambil dari penelitian ini adalah :

1. Keterbukaan (transparancy), berpengaruh terhadap kinerja karyawan. Penelitian ini menunjukkan bahwa inti dari prinsip ini dapat meningkatkan keterbukaan informasi mengenai perusahaan secara teratur dan tepat waktu serta benar sehingga pihak manajemen dapat memanajemen risiko untuk memastikan seluruh risiko dapat dikelola pada waktu yang dapat ditolelir yang akan mempengaruhi kinerja perusahaan itu sendiri.

2. Akuntabilitas (Accountability), berpengaruh terhadap kinerja karyawan. Penelitian ini menunjukkan bahwa akuntabilitas mengatur bagaimana sebaiknya perusahaan membentuk komite audit untuk memperkuat fungsi pengawasan intern oleh komisaris.

3. Tanggung jawaban (Responsibility), berpengaruh terhadap kinerja karyawan. Penelitian ini menunjukkan prinsip pertanggung jawaban ini mengatur pemenuhan tanggung jawab perusahaan sebagai entitas bisnis dalam masyarakat kepada seluruh stakeholders yang mencakup hal-hal yang terkait dengan peraturan hubungan antara perusahaan dengan seluruh stakeholders untuk mewujudkan perusahaan sebagai perusahaan yang baik.

4. Kemandirian (Independency), berpengaruh terhadap kinerja karyawan. Penelitian ini menunjukkan bahwa prinsip kemadirian dapat mengatur tentang bagaimana karyawan mampu menghindari terjadinya dominasi yang tidak wajar oleh stakeholders.

5. Kewajaran (Fairness), berpengaruh terhadap kinerja karyawan. Penelitian ini menunjukkan kewajaran meliputi kejelasan hak-hak pemegang saham untuk melindungi kepentingan pemegang saham, termasuk perlindungan terhadap pemegang saham minoritas dari kecurangan, sehingga kinerja karyawan akan stabil karena para pemegang saham mengetahui secara detail seluruh informasi perusahaan. 


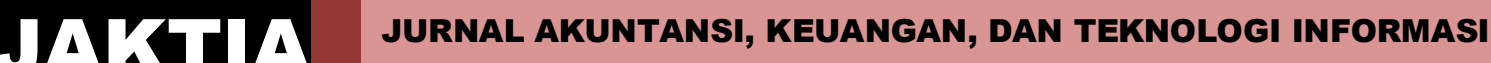

6. Transparancy, independency, accountability, responsibility, dan fairness berpengaruh terhadap kinerja karyawan. Penelitian ini menunjukan bahwa semakin baik dalam menerapkan GCG, maka akan semakin meningkat pula kinerja karyawan. Hasil kerja tersebut dapat meningkat dengan didukung oleh penerapan dari GCG yang terdiri dari prinsip Transparancy, independency, accountability, responsibility, dan fairness yang telah ditetapkan.

\section{Saran}

Berdasarkan pembahasan yang telah dikemukakan diatas mengenai pengaruh penerapan prinsip-prinsip good corporate governance pada kinerja karyawan, maka saran yang dapat peneliti kemukakan dalam penelitian ini adalah Agar hasil penelitian ini dapat sebagai bahan pertimbangan bagi pihak Bank BRI Unit Ratu Samban Kota Bengkulu agar dapat meningkatkan dan terus mengevaluasi kinerja SDM. Dengan mengimplementasi Good Corporate Governance (GCG), maka pengelolaan sumber daya manusia diharapkan menjadi efisien, efektif, dan produktif dengan selalu berorientasi pada tujuan perusahaan dan memperhatikan stakeholdernya. Serta untuk penelitian selanjutnya hendaknya memperluas populasi yang digunakan dan memperpanjang periode waktu penelitian sehingga hasil penelitian diharapkan dapat lebih relevan.

\section{DAFTAR PUSTAKA}

Akbariyeh, H. (2015). A Study of Factors Affecting on Customers Purchase Intention Case Study: the Agencies of Bono Brand Tile in Tehran'. Journal of Multidisciplinary Engineering, Science and Technology (JMEST, 2(1), 267.

Anwar Prabu Mangkunegara, (2011). "Manajemen Sumber Daya Manusia". PT. Remaja Rosdakarya.

Aries Setyowati, Sudharto P. Hadi, dan Reni Shinta Dewi "pengaruh budaya kerja dan penerapan good corporate governance terhadap kinerja karyawan pada PT. Pos Indonesia (Persero) Kantor Pos Ungaran 50500".

Cahyani, Nuswandari, 2009. Pengaruh Corporate Governance Perceptionindek terhadap Kinerja Perusahaan Manufaktur. Jurnal Manajemen Vol.16 No.2.

Daniri, Mas Ahmad, 2014, Lead By GCG. Jakarta: Gagas Bisnis.

Didin Nahrudin Syah, Rachmat Hasbullah, \& Solehudin, (2018), "Pengaruh Good Corporate Governance terhadap Kinerja Karyawan PT Pupuk Kujang Cikampek” Jurnal Bisnis, Manajemen \& Perbankan (JBMP).

Fajar Nur'aini DF, (2017). “Panduan Praktis Evaluasi Kinerja Karyawan”. PT. Anak Hebat indonesia.

Ghozali, Imam, 2018. “Aplikasi Analisis Multivariate dengan Program IBM SPSS 25”. Badan Penerbit Universitas Diponegoro: Semarang.

Hamdani, (2016). “Good Corporate Governance Tinjauan Etika dalam Praktik Bisnis". Mitra Wacana Media.

Harsuko. (n.d.). Mendongkrak Motivasi Dan Kinerja: Pendekatan Pemberdayaan SDM. Malang: UB Press. 
Jayanti Ike Febriani, Mochammad Al Musadieq, \& Tri Wulida Afriyanty, (2016), "Pengaruh Good Corporate Governance terhadap Kinerja (Studi pada Karyawan PT Pos Indonesia (persero) Tuban)" Jurnal Administrasi Bisnis.

Jimmy Joses Sembiring, (2010). "Smart HRD Perusahaan Tenang, Taryawan Senang". Transmedia Pustaka : Jakarta.

https://books.google.co.id/books?id=3iryd47hXJkC\&printsec=frontcover \&dq=smart+hrd\& $\mathrm{hl}=\mathrm{id} \& \mathrm{sa}=\mathrm{X} \& \mathrm{ved}=0 \mathrm{ahUKEwj}$ NhtaghvfoAhWEIbcAHR61BqgQ6AEIKDAA\#v=onepage \& $\mathrm{q}=$ smart $\% 20 \mathrm{hrd} \& \mathrm{f}=$ false

Keputusan menteri bumn kep-117/m-mbu/2002 tanggal 31 juli 2002penerapan praktek good corporate governance pada badan usaha milik negara (bumn).

http://jdih.bumn.go.id/lihat/KEP-117/M-MBU/2002

Komite Nasional Kebijakan Governance. 2006. Pedoman Umum Good Corporate Governance Indonesia

Lulu Unnisa, (2018), "Pengaruh Good Corporate Governance terhadap Kinerja Karyawan di BNI Syariah Cabang Fatmawati”, Jakarta : Universitas Muhammadiyah Jakarta.

M. Firza Alpi, 2019. Penerapan Good Corporate Governance pada PT. Bank BUMN Tbk Regional I Sumatera Utara. Proseding Seminar Nasional Kewirausahaan, 1(1), 2019, hal 355-364 Hasil Penelitian dan Pengabdian Kepada Masyarakat ISSN 2714-8785.

Mathis, R. L. \& J. H. J. (2006). Human Resource Management: Manajemen Sumber Daya Manusia. Jakarta: Salemba Empat

Marniati, 2010. Analisis Penerapan Prinsip Good Corporate Governance (GCG) terhadap Kinerja Karyawan di Bagian Administrasi Umum Rumah Sakit Umum Daerah Dr. Zainoel Abidin Banda Aceh.

Moh. Wahyudi Zarkasyi, (2014), “Good Corporate Governance Pada Badan Usaha Manufaktur, Perbankan, dan Jasa Keuangan Lainnya". Gagas Bisnis Indonesia.

Mutamimah dan Phradiansah. 2014. Analisis Implementasi Good Corporate Governance Terhadap Kinerja Sdm Melalui Organizational Commitment EKOBIS. Vol.15 (2).

Saiful Amri, Andi Tri Haryono, \& M Mukery (2016), "Pengaruh Good Corporate Governance terhadap Kinerja Karyawan PT Editec Cakrawiyasa Semarang" Journal of Management. ISSN : 2502-7689.

Suci, Y. F. dan S. Khairani. 2010. Pengaruh Penerapan Prinsip Good Corporate Governance Terhadap Kinerja Perusahaan Pada PT KERETA API (Persero) Divisi Regional III Sumatera Selatan. Jurnal. Akuntansi. STIE MDP. Palembang.

Sugiyono, (2017), "Metode Penelitian Kuantitatif, kualitatif, dan R\&D”. Alfabeta : Bandung. 